\title{
COMMENT OPEN
}

\section{Is aberrant $\mathrm{CD} 8+\mathrm{T}$ cell activation by hypertension associated with cardiac injury in severe cases of COVID-19?}

\author{
Chao Zhang ${ }^{1}$, Fu-Sheng Wang ${ }^{1}$, Jean-Sébastien Silvestre ${ }^{2}$, Fernando Arenzana-Seisdedos ${ }^{3}$ and Hong Tang $^{3}$ \\ Cellular \& Molecular Immunology (2020) 17:675-676; https://doi.org/10.1038/s41423-020-0454-3
}

COVID-19 global pandemic, caused by severe acute respiratory syndrome coronavirus type 2 (SARS-CoV-2), ${ }^{1}$ has swept 185 countries and regions with more than $2,824,728$ confirmed cases, and 197,667 death as on April 25, 2020 according the Coronavirus Resource Center at Johns Hopkins University. Accumulating data suggest that hypertension, diabetes, and cardiovascular diseases are the most frequent comorbidities in COVID-19 patients, and case mortality rates tended to be high in these individuals. ${ }^{2}$ Among few studies that focus on COVID-19 severe pneumonia, cardiovascular diseases are among the most frequent comorbidities, $^{3-5}$ with hypertension being the most common (58 of 191 patients, 30\%) in one study, exceeding twofold in COVID-19 ARDS patients ( 23 of $84,27.4 \%$ ) more than mild patients (16 of 117 , $13.7 \%$ ) in another study.

Angiotensin II (Ang II) is a potent hypertensive hormone, and increased Ang II is associated with hypertension and heart failure, ${ }^{6}$ lung $^{7}$ and renal dysfunction. ${ }^{8}$ Angiotensin-converting enzyme 2 (ACE2) converts Ang II to Ang 1-7 to negatively regulate the renin-angiotensin system (RAS) and renin-angiotensin-aldosterone system. ${ }^{9}$ SARS-CoV-2 binds to the catalytic domain of ACE2, with higher binding affinity than SARS-CoV, for cell entry. ${ }^{10-12}$ Notably, SARS-CoV Spike protein engagement can downregulate ACE2 expression and activate RAS for lung injury. ${ }^{13}$ Furthermore, plasma level of Ang II is markedly elevated and correlated to viral load and lung injury of COVID-19 patients. ${ }^{14}$ Therefore, reduction of cell surface ACE2, due to SARS-CoV-2 endocytosis, would augment Ang II pathological processes in the development of hypertension, cardiomyopathy, and nephropathy ${ }^{15}$ in severe COVID-19 patients.

Hypertension is treated with ACE inhibitors and angiotensin II type-I receptor blockers (ARBs), resulting in ACE2 upregulation. It is unclear whether ARB/ACE regime is warranted in COVID-19, due to insufficient evidence at the moment. European Society of Cardiology recommends not to change RAS blockade in COVID19 patients who are on it, unless adverse clinical indications occur. Further study needs to better understand the impaired RAS in the viral pathogenesis of COVID-19.

ACE2 is highly expressed in the heart tissue, implicating a possibly direct viral infection of the myocardium. Strikingly, two independent postmortem examinations revealed no evidence of viral infection or replication in cardiac tissues, albeit pronounced cardiac inflammation exists. ${ }^{16,17}$ It is unlikely that viral infection and replication directly cause or aggravate cardiac injury in these severe patients. It is becoming recognized that macrophages and $T$ cells infiltrate to the heart in response to hypertension, and the end-organ damage are in part mediated by activation of these infiltrated cells. ${ }^{18}$ Our lab showed that mice lacking CD8+ T cells are efficiently protected from hypertension-induced cardiac damage. $\mathrm{CD} 8+\mathrm{T}$ cells thus can sense the hypertension independent of $\mathrm{T}$ cell receptor. ${ }^{19}$ More importantly, CD8+ T cells are required for macrophage infiltration in myocardium and subsequent activation by CD8 + T cells secreted IFN- $\gamma$.

How do CD8 $+\mathrm{T}$ cells respond to hypertension? One study suggests that mineralocorticoid receptor on CD8 + T cells directly sense blood pressure and promote inflammatory milieu through secreting IFN- $\gamma^{20,21}$ Furthermore, hypertension can trigger oxidative modification of proteins in DC cells by highly reactive $\gamma$-ketoaldehydes (isoketals), which activate DC to produce IL-6, IL$1 \beta$, and IL-23. Activated DCs promote T cell, particularly CD8+ T cell, proliferation and production of IFN- $\gamma$ and IL-17A. ${ }^{22}$ Intriguingly, a secondary hemophagocytic lymphohistiocytosis, which associates with a massive CD8 $+\mathrm{T}$ cell and macrophage activation but decreased NK cell activity, has been noted for COVID-19 patients in European ICUs. Taken together, these results suggest that CD8+ T cells may function as a key hypertension effector that drives macrophage-mediated cardiac damage.

Severe COVID-19 patients also showed increased IL-6, IL-1 $\beta$, and IFN- ${ }^{23}$ It is worthy of studying whether blockade of IL- 6 or IL-1 $\beta$, which is currently under clinical trials, would reduce cardiac injury through inhibition of $\mathrm{CD}^{+} \mathrm{T}$ cell-macrophage infiltration and overactivation. The glucocorticoid treatment of ICU patients shall also be closely monitored for potential beneficial or detrimental effect on $\mathrm{CD}^{+} \mathrm{T}$ cell activation. Lastly, CCR5 is a major chemoattracting receptor in $\mathrm{CD}^{+}{ }^{+} \mathrm{T}$ cells that involves in various pathogenic conditions, including viral infections. ${ }^{24}$ The antiviral drugs, such as Selzentry (maraviroc) and Leronlimab (PRO 140), have been successfully used for treatment of AIDS. ${ }^{25}$ It is therefore of great interest to study whether these drugs can block cardiac infiltration of $\mathrm{CD}^{+} \mathrm{T}$ cells thereby reduce hypertensive cardiac injury of COVID-19 patients.

\section{ADDITIONAL INFORMATION}

Competing interests: The authors declare no competing interests.

\section{REFERENCES}

1. Zhu, N. et al. A novel coronavirus from patients with pneumonia in China, 2019. N. Engl. J. Med 382, 727-733 (2020).

\footnotetext{
${ }^{1}$ Treatment and Research Center for Infectious Diseases, The Fifth Medical Center of PLA General Hospital, National Clinical Research Center for Infectious Diseases, Beijing, China; ${ }^{2}$ Inserm UMRS 970, Paris Centre de Recherche Cardiovasculaire (PARCC), 75737 Paris cedex 15, Cedex, France and ${ }^{3}$ CAS Key Laboratory of Molecular Virology and Immunology, COVID-19 Response Team, Institut Pasteur of Shanghai, Chinese Academy of Sciences, Shanghai, China

Correspondence: Hong Tang (htang@ips.ac.cn)
}

Received: 16 April 2020 Accepted: 26 April 2020

Published online: 12 May 2020 
2. Bavishi, C., Maddox, T. M. \& Messerli, F. H. Coronavirus disease 2019 (COVID-19) infection and renin angiotensin system blockers. JAMA Cardiol. https://doi.org/ 10.1001/jamacardio.2020.1282 (2020).

3. Yang, X. et al. Clinical course and outcomes of critically ill patients with SARS-CoV2 pneumonia in Wuhan, China: a single-centered, retrospective, observational study. Lancet Respir Med. https://doi.org/10.1016/s2213-2600(20)30079-5 (2020).

4. Zhou, F. et al. Clinical course and risk factors for mortality of adult inpatients with COVID-19 in Wuhan, China: a retrospective cohort study. The Lancet. 395, 1054-1062 (2020).

5. Wu, C. et al. Risk factors associated with acute respiratory distress syndrome and death in patients with coronavirus disease 2019 pneumonia in Wuhan, China. JAMA Int. Med. https://doi.org/10.1001/jamainternmed.2020.0994 (2020).

6. Crackower, M. A. et al. Angiotensin-converting enzyme 2 is an essential regulator of heart function. Nature 417, 822-828 (2002).

7. Imai, Y. et al. Angiotensin-converting enzyme 2 protects from severe acute lung failure. Nature 436, 112-116 (2005).

8. Torres, V. E. et al. Angiotensin blockade in late autosomal dominant polycystic kidney disease. N. Engl. J. Med. 371, 2267-2276 (2014).

9. Santos, R., Ferreira, A. J., Verano-Braga, T. \& Bader, M. Angiotensin-converting enzyme 2, angiotensin-(1-7) and Mas: new players of the renin-angiotensin system. J. Endocrinol. 216, R1-R17 (2013).

10. $\mathrm{Xu}, \mathrm{X}$. et al. Evolution of the novel coronavirus from the ongoing Wuhan outbreak and modeling of its spike protein for risk of human transmission. Sci. China Life Sci. 63, 457-460 (2020).

11. Yan, R. et al. Structural basis for the recognition of SARS-CoV-2 by full-length human ACE2. Science 367, 1444-1448 (2020).

12. Hoffmann, M. et al. SARS-CoV-2 Cell Entry Depends on ACE2 and TMPRSS2 and Is Blocked by a Clinically Proven Protease Inhibitor. Cell 181, 271-280.e278 (2020).

13. Kuba, K. et al. A crucial role of angiotensin converting enzyme 2 (ACE2) in SARS coronavirus-induced lung injury. Nat. Med. 11, 875-879 (2005).

14. Liu, Y. et al. Clinical and biochemical indexes from 2019-nCoV infected patients linked to viral loads and lung injury. Sci. China Life Sci. 63, 364-374 (2020).

15. Cheng, Y. et al. Kidney disease is associated with in-hospital death of patients with COVID-19. Kidney International 97, 829-838 (2020).

16. Yao, X. H. et al. [A pathological report of three COVID-19 cases by minimally invasive autopsies]. Zhonghua bing li xue za zhi Chin J Pathol 49, E009, https://doi. org/10.3760/cma.j.cn112151-20200312-00193 (2020).
17. $\mathrm{Xu}, \mathrm{Z}$. et al. Pathological findings of COVID-19 associated with acute respiratory distress syndrome. Lancet Respir. Med. 8, 420-422 (2020).

18. Frieler, R. A. \& Mortensen, R. M. Immune cell and other noncardiomyocyte regulation of cardiac hypertrophy and remodeling. Circulation 131, 1019-1030 (2015).

19. Ma, F. et al. The requirement of CD8+ T cells to initiate and augment acute cardiac inflammatory response to high blood pressure. J. Immunol. 192, 3365-3373 (2014).

20. Sun, X.-N. et al. T-cell mineralocorticoid receptor controls blood pressure by regulating interferon-gamma. Circ. Res. 120, 1584-1597 (2017).

21. Barbaro, N. R., Kirabo, A. \& Harrison, D. G. A new role of mister (MR) $T$ in hypertension: mineralocorticoid receptor, immune system, and hypertension. Circ. Res. 120, 1527-1529 (2017).

22. Kirabo, A. et al. DC isoketal-modified proteins activate $T$ cells and promote hypertension. J. Clin. Investig. 124, 4642-4656 (2014).

23. Huang, C. et al. Clinical features of patients infected with 2019 novel coronavirus in Wuhan, China. Lancet 395, 497-506 (2020).

24. Glass, W. G. et al. CCR5 deficiency increases risk of symptomatic West Nile virus infection. J. Exp. Med. 203, 35-40 (2006).

25. Vangelista, L. \& Vento, S. The expanding therapeutic perspective of CCR5 blockade. Front. Immunol. 8, 1981 (2017).

(c) Open Access This article is licensed under a Creative Commons adaptation, distribution and reproduction in any medium or format, as long as you give appropriate credit to the original author(s) and the source, provide a link to the Creative Commons license, and indicate if changes were made. The images or other third party material in this article are included in the article's Creative Commons license, unless indicated otherwise in a credit line to the material. If material is not included in the article's Creative Commons license and your intended use is not permitted by statutory regulation or exceeds the permitted use, you will need to obtain permission directly from the copyright holder. To view a copy of this license, visit http://creativecommons. org/licenses/by/4.0/.

(c) The Author(s) 2020 